\title{
STIMULATION OF STUDENTS' COGNITIVE ACTIVITIES IN THE PROCESS OF FOREIGN LANGUAGE LEARNING
}

\author{
${ }^{1}$ Hadaichuk Nataliia, ${ }^{2}$ Herasymenko Nadiia, ${ }^{3}$ Melnyk Olesia, \\ ${ }^{4}$ Nykyporets Svitlana, ${ }^{5}$ Slobodianiuk Alla \\ Ukraine, Vinnytsia, Vinnytsia National Technical University \\ ${ }^{1}$ Lecturer in foreign languages \\ ${ }^{2}$ Lecturer in foreign languages \\ ${ }^{3}$ Ph.D., Senior lecturer in foreign languages \\ ${ }^{4}$ Lecturer in foreign languages \\ ${ }^{5}$ Senior lecturer in foreign languages
}

DOI: https://doi.org/10.31435/rsglobal_ws/31032020/6984

\section{ARTICLE INFO}

Received: 12 January 2020

Accepted: 15 March 2020

Published: 31 March 2020

\section{KEYWORDS}

students,

technical university,

cognitive activity stimulation,

learning process,

foreign languages,

increasing motivation.

\begin{abstract}
Currently the stimulation of students' cognitive activity in learning a foreign language is one of the most pressing problems of pedagogy. In organizing the educational process of a foreign language, the motivation of students plays a significant role. Successful student motivation helps to set priorities, activate and concentrate thinking, increase interest in learning a foreign language as a whole and perform specific tasks in particular. The article considers the most relevant and actual methods of stimulating students' cognitive activity in the modern technical nonlinguistic university, aimed at modern youth, their interests and hobbies. The most expedient methods of activating students' educational activities have been mentioned.
\end{abstract}

Citation: Hadaichuk Nataliia, Herasymenko Nadiia, Melnyk Olesia, Nykyporets Svitlana, Slobodianiuk Alla. (2020) Stimulation of Students' Cognitive Activities in the Process of Foreign Language Learning. World Science. 3(55), Vol.3. doi: 10.31435/rsglobal_ws/31032020/6984

Copyright: (C) 2020 Hadaichuk Nataliia, Herasymenko Nadiia, Melnyk Olesia, Nykyporets Svitlana, Slobodianiuk Alla. This is an open-access article distributed under the terms of the Creative Commons Attribution License (CC BY). The use, distribution or reproduction in other forums is permitted, provided the original author(s) or licensor are credited and that the original publication in this journal is cited, in accordance with accepted academic practice. No use, distribution or reproduction is permitted which does not comply with these terms.

Introduction. The development of international relations and cooperation in various spheres of economy, politics, culture and science can be accomplished with the help of highly qualified specialists who are fluent in foreign languages.

The necessity to achieve a new level of specialists training led to the search for tools and new directions in foreign language studies.

The process of activating students' cognitive activity is an integral part of the process of learning and contributes to the formation of such qualities as inquisitiveness, initiative, diligence, etc. $[1,3]$ That is why the revitalization of cognitive activity is one of the most pressing problems of higher education, the solution of which gives the opportunity to improve the level of knowledge and contribute to the formation of students' creative personality.

The mechanisms of cognitive activity stimulation, based on methodical principles of teaching foreign languages, are revealed in the works of well-known methodologists such as E. P. Shubina, G. V. Rogova, E. I. Pasov. [5]

Learning foreign languages has its own characteristics, which are not peculiar to other disciplines in the field of methodology, individual approach, means and methods of activating cognitive activity. [2, 4] This problem has not been sufficiently developed theoretically and methodically. 
Research results. One of the components of increasing motivation and activating the cognitive activity of students is the use of the Internet. The Internet naturally comes into the lives of students and is one of the most effective tools to help greatly diversify the learning process.

Advanced pedagogical experience and our own experience of working with students at the faculties of VNTU shows that every lesson with the use of Internet sites causes emotional uplift; even students who at first do not show good results are happy to work with a computer. As we think, at the same time, poor online test results are caused by gaps in knowledge and make them seek help from the teacher or to acquire this knowledge themselves. It is also interesting, as N.G. Ovsyan testifies, that in the process of computer-educational-gaming activity there is a "cooperative effect" - the students in the educational game against the computer unconsciously help each other, transfer knowledge to those who know less. Therefore, such an invaluable student-student relationship is formed $[6,9]$.

Using the World Wide Web has many advantages:

$\checkmark$ application at different stages of training;

$\checkmark$ possibility of application at any stage of work on practical training;

$\checkmark$ learning material is better understood and easier to remember;

$\checkmark$ economical use of study time;

$\checkmark$ individualization of learning, determination of the depth and sequence of assimilation, pace of work;

$\checkmark$ reducing the types of work that cause student tiredness;

$\checkmark$ the use of various audio-visual learning tools (graphics, sound) to enrich and motivate learning, visual and dynamic presentation of material;

$\checkmark$ branching of the learning sequence based on error analysis;

$\checkmark$ creating a comfortable environment for modern learning;

$\checkmark$ activation of the student's educational activity;

$\checkmark$ intensification of training and increase the level of motivation;

$\checkmark$ formation of student's self-esteem and creation of conditions for his independent work.

With the help of the Internet, students can perform the following types of learning activities: training spelling, studying lexical material, improving understanding of audio text, developing reading technique, studying grammar, learning written language, practicing pronunciation, etc.

The Internet allows you to successfully simulate the conditions of communicative activity, to implement them in various situational exercises.

Today, the World Wide Web contains a large number of sites with potentially interesting and relevant educational material.

The issue of intensification of foreign language learning is based on the system of mutual action of a teacher and a group of students.

The main way to improve the content of study depends on the student body and involves the following forms of work:

1. Rational use of educational material with the allocation of basic, secondary, additional one in it.

2. Redistribution of material with the maximum concentration of new one at the initial stage of training.

3. Economical and rational use of every minute of working time.

4. Activation of potential opportunities of the student in conditions of creative interaction of the teacher and the student.

5. Creating a favourable psychological "microclimate" in the audience, this provides for a trusting attitude of teachers to students and vice versa.

Thanks to these forms of work, there is an understanding of intensity that requires minimum time to achieve maximum learning outcomes.

These forms of work are not new by themselves, but for some reason teachers sometimes forget about them, admiring the purely theoretical teaching of material that causes students rapid tiredness and apathy.

To maximize the potential of each student, the following points should be considered:

a) release the student from the feeling of insecurity on the basis of trust;

b) think of encouragement that would allow students to believe in themselves;

c) organize a number of roleplaying business games to increase interest in learning foreign languages. 
An important place at all these stages of learning is given to the teacher, who, in intensive forms of learning, plays mostly the role of a partner in communication.

The main contradiction between students' level of knowledge, their communicative competence and the ability to communicate in a variety of life and professional situations can be found through the use of such forms of learning that stimulate students' cognitive activity. These include:

1. Annual students' conferences. Students make interesting presentations in a foreign language. In the course of preparation large volume of material in a foreign language is processed. During these types of work, students are more actively trained in monologue and dialogical types of speech, in the ability to ask questions of a controversial nature, in a logical way to answer questions.

2. Thematic soiree are held together with the Scientific and Technical Library of the University for important and memorable dates, evenings dedicated to W. Shakespeare, G. Byron, R. Kipling, R. Burns, etc. It stimulates intellectual activity of students, their independence, helps to express their thoughts better.

3. Conducting Foreign Language Days at the University. The Foreign Language Day program includes Olympiads, Soirées and literature exhibitions. Each participant of the soirée receives a task, during which he learns something new, acquires certain skills that activate their creative potential.

4. Conversations on modern events. In preparation, students use articles from Internet newspapers, magazines, radio broadcasts, television, and information from the media that expands their outlook.

5. Quizzes. We use visual materials conducting quizzes. In practice, students can apply the knowledge gained in the classes, which encourages them to improve their knowledge, linguistic and spoken luggage.

It should be noted that the department of foreign languages is constantly conducting classes using this or that method in particular or in combination with others. Problematic discussions of the studied topics, discussions, dialogues are an integral part of every foreign language lesson. Their goal is to improve students' previously acquired skills (speaking and listening).

As you know, the most important principle of learning is the principle of combining different methods and techniques of learning. The skill of the teacher is to choose the optimal combination of methods and teaching aids, methodical techniques that provide activation of cognitive activity, which is a catalyst for teaching and learning.

When we speak about the issue of intensifying the attention of students of higher education institutions for learning a foreign language, attention should be paid both to improving the theoretical level of educational material, as well as to acquaintance and teaching with the methods of cognition, independent work and self-motivation.

There are quite a number of ways and methods of activating students' attention in learning a foreign language. First, the simplicity and accessibility of the teacher's language, as well as familiar terms, which are constantly repeated, allows supporting the student's interest to the material under study. Equally important is the level of the material. An important role in enhancing students' attention in learning a foreign language is given to a sign language. Gestures and facial expressions can greatly increase the effectiveness of language perception.

For foreign language material to be perceived effectively, it should be "standardized". This does not mean that you need to take one element to study, process it, master it and finish the lesson. Effectiveness of mastering the learning material is significantly increased if different methods and channels are used for its processing. For example, it is possible to use different types of memory: visual, aural, motor, emotional, verbal-logical, which is quite possible when changing the types of speech activity (writing, reading, speaking and listening). In addition, we may say that questions are very important to stimulate interest of students. Moreover, these should rather be the questions from the students. A properly asked question can lead to a broad discussion on some particular issue and to stimulate students' interest in the topic being explored as a whole.

Emotional aspects should be emphasized in enhancing the attention of foreign language learners. The concept of "emotional involvement" has become widespread. In order to stimulate students' interest in the subject or material from the beginning of the studies, the very beginning of the lesson should be unusual, bright, and to some extent extraordinary. This can be achieved by submitting an interesting historical fact, interesting information about the subject of the lesson, vivid examples of literature, science, etc.

To positively stimulate students' interest in the foreign language material under study, it is possible to create a healthy competition in the audience. Influence on self-esteem has a great influence on students' 
activities. This method of activating students' attention when learning a foreign language is also good because it can and desirably be used in groups or subgroups, enabling the whole group of students to be involved and energized, rather than individual elements of it. In this case, a positive result is ensured anyway, because at least one subgroup wins, and the loser will try to strive for success next time.

Another way to increase the focus of students learning a foreign language is to deliberately make a mistake. The teacher can draw students' attention to the presence of a mistake at the very beginning of the lesson and thus ensure the students' lasting interest throughout the lesson. In addition, it gives a positive impetus to students, showing that they have information (such as grammar, if a grammatical error is made in the exercise) at the teacher level.

Along with the introduction of innovative foreign language learning technologies and the implementation of distance learning courses, the teacher remains a key figure in this aspect. In addition to a variety of special forms, methods, techniques and learning tools aimed directly at activating and stimulating student activity, personal influence on the teacher is important.

Conclusions. The stimulation of students' cognitive activity in learning a foreign language is one of the most pressing problems of pedagogy. In organizing the educational process of a foreign language, the motivation of students plays a significant role. Successful student motivation helps to set priorities, activate and concentrate thinking, increase interest in learning a foreign language as a whole and perform specific tasks in particular. An important aspect of stimulating and activating student attention is evaluating students' work. When we inform students about the possibility of obtaining positive marks or extra points, it supports students' interest in learning a foreign language, increases their interest in acquiring new knowledge, skills and abilities.

Using the above methods, the teacher has the opportunity to make the process of learning a foreign language rich, interesting and highly effective. Nowadays, to stimulate students' attention, it is possible to use innovative computer technologies (presentations, grammar, lexical material), which supports the interest of students throughout the class (visual material is perceived easier and can be memorized better).

Thus, according to the results of our study, we can conclude that in modern educational environment, the use of multimedia technologies is becoming more accessible and has a positive impact on the process of learning a foreign language.

\section{REFERENCES}

1. Бех І. Д. Духовні цінності в розвитку особистості // Педагогіка і психологія. - 2007, №1, с. 124 - 129.

2. Близнюк О. І., Панова Л. С. Ігри у навчанні іноземних мов: посібник для вчителів / О. І. Близнюк, Л. С. Панова. - Київ : Освіта, 2007. - 64 с.

3. Галопова С. В. Сучасні методи викладання іноземних мов за рубежем / С. В. Галопова // Іноземні мови. - 2010. - № 4. - С. 24.

4. Джава Надія. Проблемні методи навчання іноземних мов. Дискусія. / Надія Джава // Нова педагогічна думка. - 2005. - № 3. - С. 49.

5. Китайгородська Г. А. Методичні основи навчання іноземним мовам. - М., 2015.

6. Кондратюк I. Г. Активізація навчальної діяльності учнів на уроці / І. Г. Кондратюк // Англійська мова та література. - 2006. - № 15. - С. 2.

7. Методика викладання іноземних мов у середніх навчальних закладах: підручник. - Вид. 2-е, випр. I перероб. / С. Ю. Ніколаєвої. - Київ: Ленвіт, 2002. - 328 с.

8. Мілютіна 3. Т. Впровадження інтерактивних технологій навчання на уроках іноземної мови / 3. Т. Мілютіна // Управління школою. - 2005. - № 19-21. - С. 49-51.

9. Овсяна Н. Г. Ресурси Інтернет для вивчення англійської мови / Н. Г. Овсяна // Англійська мова та література. - 2011. - № 19-21. - С. 47-49.

10. Огієвич О. Дидактична гра - шлях до підвищення якості навчання і виховання учнів. Анотація досвіду / О. Огієвич // Нова педагогічна думка. - 2005. - № 1. - С. 83.

11. Осадчук Р. І. Дидактичні ігри у навчальному процесі школи / Р. І. Осадчук // Педагогіка і психологія. - 1996. - № 4. - С. 102-110.

12. Панаетова О. А. Використання методу проектів на уроках країнознавства / О. А. Панаетова // Англійська мова і література. - 2003. - № 30. - С. 15-19.

13. Петрушинський В.В. Методика інтенсивного навчання. - М., 2018.

14. Полат Е. С. Метод проектов на уроках иностранного языка / Е. С. Полат // Иностранные языки в школе. - 2000. - № 2-3. - С. 15-34.

15. Потапенко С., Тезікова С. Пошук нових лінгво-педагогічних технологій навчання англійської мови / С. Потапенко, С. Тезікова // Рідна школа. - 2000. - серпень. - С. 65-67.

16. Сергєєва О. Використання комп'ютерних програм на уроках англійської мови / О. Сергєєва. English. - 2008. - № 31-32. - C. 10-17. 
17. Скорнякова М. Є. Сучасні методи викладання англійської мови / М. С. Скорнякова // Англійська мова та література. - 2005. - № 28. - С. 2-12.

18. Ходос Б. Метод проектів як один як один з прийомів активізації пізнавальної діяльності учнів у викладанні іноземної мови / Б. Ходос // Рідна школа. - 2005. - № 5. - С. 79-80.

19. Чернилевський Д.В., Філатов О.К. Педагогіка вищої школи: Підручник. - К.: Либідь, 2007.

20. Rotgans, J.I. and H.G. Schmidt, 2014. Situational interest and learning: Thirst for knowledge. Learning and Instruction, UK: 37-50.

21. Hervas, A., F.B. Garcia and F.J. Penalvo, 2014. A Method of Assessing Academic Learning Experiences in Virtual Learning Environments. IEEE Latin America Transactions, USA: 219-226.

22. Hawkridge, D.R., J. Jaworski and H. McMahon, 2000. Computers in Third World Schools: examples, experiences and issues. London: Macmillan, pp: 275.

23. Boucher, A., 1998. Information technology - based teaching and learning in higher education: a view of the economic issues. J. Of Information Technology for Teacher Education, Dublin: 67-71.

24. Cookson, P., 2000. Implications of Internet technologies for higher educations: North American perspectives. Open Learning: 14-21. 